\title{
"Context matters": The challenges and opportunities of designing tertiary public and environmental health education in South Auckland
}

Kate Kersey, Amanda B Lees, Cath Conn, Thom Cochrane, Margaret Williams, Vickel Narayan

\begin{abstract}
This article outlines a study protocol, detailing the proposed methodology and findings of our preliminary literature review, for co-design of future NZ public and environmental health education for the South Auckland campus of AUT University. This research project aims to contribute to healthy communities and city, embrace emerging technologies, maximize youth employability, and develop an outstanding 21 st Century tertiary environment. The proposed project would contribute to a significant re-conceptualization of curriculum; student learning and voice; and partnerships with communities and a fast-changing industry. Using a designbased research approach to curriculum development, the research practitioners in this project would immerse themselves in the context of the project, be guided by emerging theory in developing design principles, construct features of an intervention and evaluate the impact on teaching and learning. Situated in Kaupapa Māori and Pacific epistemologies and utilising collaborative design principles, the study would explore the diverse and complex context in which public and environmental health will be provided at AUT South. Of particular relevance would be an examination of the following drivers of tertiary, and public and environmental health, education in the $21^{\text {st }}$ century: the unique South Auckland context, the need to embrace evolving concepts of public health, rapid technological change, and changing education paradigms. Our ultimate goal is to develop co-designed interventions that accommodate the unique cultural and ethnic makeup of the South Auckland context with the opportunity for transferability across the tertiary sector, situated within a social constructivist philosophy appropriate for our new digital economy and environmental challenges.
\end{abstract}

Keywords: tertiary education, social constructivist, design-based research, public and environmental health

The authors are a group of AUT researchers and practitioners, in the public health and teaching and learning fields, who are passionate about curriculum redesign and innovative learning and teaching strategies, to reflect the needs and opportunities of the 21 st century. The authors are members of Te Kura Hauora Tümatanui/School of Public Health and Psychosocial Studies, and the Centre for Learning and Teaching, Auckland University of Technology. Correspondence kate.kersey@aut.ac.nz.

\section{Introduction}

Design-based researchers exhort education practitioners developing new curricula to situate themselves within the social and political contexts of their practice, embracing their "messiness", as they design interventions addressing local issues and dynamics (Barab \& Squire, 2004). Using design principles based on existing theories and knowledge to address local situations, these researchers also aim through iterations of action not only to provide effective curricula but to refine existing and develop new theory (Barab \& Squire, 2004). The opening of the South Auckland campus of the Auckland University of Technology (AUT) at Manukau (AUT South) - with government funding for significant student numbers up to 4000 
equivalent full-time students (EFTs) - provides the opportunity to marry context and theory in developing public and environmental health education in service of this community.

A group of AUT researchers and practitioners in the public and environmental health and teaching and learning fields are seeking to embark on curriculum redesign to be facilitated at AUT South that aims to build an agile workforce to navigate public and environmental health issues in the $21^{\text {st }}$ century. In undertaking this, we would move away from the "business as usual" approach to a collaborative curriculum co-design process. Ultimately, interventions based on continuously evolving design principles would be implemented and evaluated in accordance with the framework set out by McKenney and Reeve:

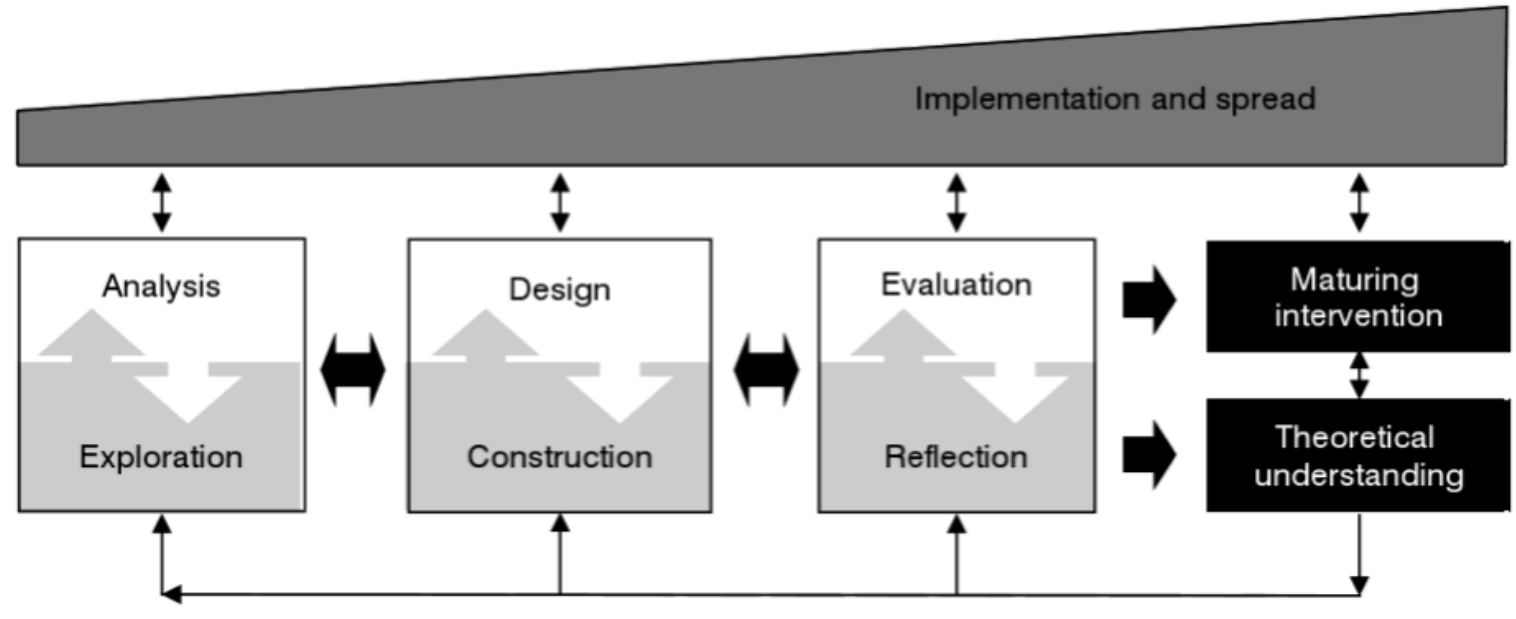

Figure 1: (McKenney and Reeve, 2012, p.77) Generic model for conducting design research in education)

This article outlines the justification for the choice of design-based methodology and introduces the findings from a preliminary exploration and analysis of the literature. In doing so, we outline the rich context in which this the project would occur, the emerging pedagogical theories that have resonance, and how approaching this as a design-based research project would add to the scholarship of teaching and learning at the tertiary level.

\section{Public Health at AUT South}

The opening of AUT South and provision of government funding in an otherwise costconstrained education system highlights importance of South Auckland as an educational priority for the government. South Auckland's context is characterised by diversity, vibrancy and a youth population. However, these communities (Mangere-Otahuhu, Otara-Papatoetoe and Manurewa) are also characterised by lower socio-economic status and have not benefited well from traditional education strategies (Ministry of Social Development/Te Manatū Whakahiato, Ministry of Justice/Tahū o te Ture, Ministry of Education/Te Tāhuhu o te Mātauranga, New Zealand Police, Nga Pirihimana O Aotearoa, Ministry of Youth Development/Te Manatū Whakahiato Taiohi, and Counties Manukau District Health Board, 2006). In the context of Ka Hikitia: "Accelerating Success 2013-2017" and the Government's "Tertiary Education Strategy", the educational needs of the high proportions of youth especially Māori and Pacific Island students are paramount (Ministry of Education/Te Tāhuhu o te Mātauranga, nd; Ministry of Business, Innovation and Employment/Hīkina Whakatutuki and Ministry of Education/Te Tāhuhu o te Mātauranga, 2014). As well as educational and socio-economic disadvantage, South Auckland communities experience poor health outcomes and improving health and reducing inequities are key objectives of the Ministry of Health/Manatū Hauora (2014; 2016). 
In December 2016, in order to strengthen student, business and wider communities' education and partnership aspirations, Te Kura Hauroa Tümatanui/School of Public Health and Psychosocial Sciences moved the existing suite of undergraduate and postgraduate public and environmental health programmes to AUT South. This move has provided the impetus and opportunity for curriculum redesign. As education practitioners, we acknowledge a number of interdependent drivers of change in the delivery of tertiary education and, in our case, public health (Figure 2). These drivers can be summarised as: the unique South Auckland context, the need to embrace evolving concepts of public health, rapid technological change and changing education paradigms.

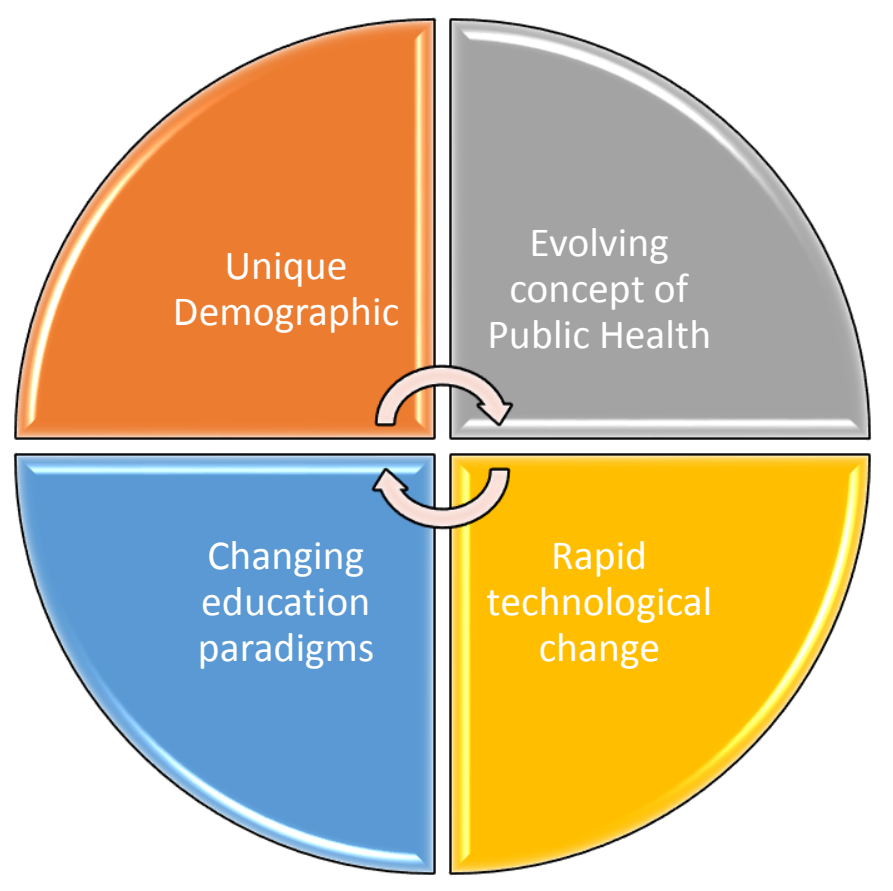

Figure 2: Drivers of change in public and environmental health in the $21^{\text {st }}$ century

While these drivers create opportunities for current and future mid to senior level professionals and for the use of technology in both education and the workforce, they also lead to uncertainty as to future workforce requirements and the skills and attributes that will be required. In this context, the overarching goal of the curriculum redesign would be to build the capacity of future mid- to senior-levels of the public and environmental health workforce through the development of appropriate skills and attributes, integration of interdisciplinary perspectives, and an in-depth understanding of the ethical and cultural issues within the context of Aotearoa New Zealand.

\section{A co-designed curriculum model for public and environmental health}

Curriculum change occurs in universities throughout the world on a daily basis. There is, however, a movement in teaching and learning to ensure that curricula changes and innovations are evidence based and the scholarship of teaching and learning is flourishing both in relation to indigenous education and evolving pedagogy as will be detailed below. As research aims to add to the body of knowledge, it necessarily requires a departure from "business as usual" requiring the testing of innovative and novel approaches. Appropriately designed research allows for "sound methodological argument" to ensure the credibility of evidence (Barab \& Squire, 2004, p. 7) in the shared results of interventions. 
Accordingly, a design-based research approach to curriculum development is proposed in this protocol. In undertaking this approach, the research practitioners in this project would immerse themselves in the context of the project, be guided by emerging theory, develop and refine appropriate design principles, iteratively develop features of an intervention, and evaluate the impact on teaching and learning (Barab \& Squire, 2004, p. 8). This approach enables existing theory to be refined and new theory to be developed, testing both the process of the development and the product itself when looking at outcomes for students. As stated by Wang and Hannafin, "... researchers manage research processes in collaboration with participants, design and implement interventions systematically to refine and improve initial designs, and ultimately seek to advance both pragmatic and theoretical aims affecting practice" (2005, p. 6). The development and ongoing refinement of design principles to guide interventions is a central feature of this process.

A key factor for the choice of this model is its central tenet of collaborative, contextual research, able to embrace Māori and Pacific epistemology or world views which advocate shared responsibility of those involved, as integral to the development of the underlying design principles. Torres and Moraes maintain that ensuring curricula responsive to students or communities involves "democratic participation of the parties at stake in the planning of the curriculum, as well as students' experiences and interests as part of the curriculum implementation" (2006, p. 348). Therefore, the shifts in teaching and learning pedagogy that focus on collaboration, co-design and giving a voice to under-served members of society, sit well with collaborative research methodologies. This approach has been found in a number of studies to balance traditional power relations inherent in the university context, recognising the leadership potential of all participants, irrespective of age and status (Samuelson, Smith, Stevenson, \& Ryan, 2013; Livingstone, Celemencki, \& Calixte, 2014; Goldstein, Ick, Ratang, Hutajulu, \& Blesia, 2016; Daddow, 2016). The approach of encouraging the sharing of knowledge, power and control through the processes of reciprocity and feedback as a partnership principle towards achieving a common interest would therefore be embedded within the framework.

The research would bring together researchers with expertise in teaching and learning from the Centre for Learning and Teaching at AUT ("CfLAT") and public health, with expertise in Kaupapa Māori and Pacific research and design-based research. Within both CfLAT and AUT public and environmental health disciplines, a strong focus already exists on collaborative and participatory methodologies (Waite \& Conn, 2011; Maibvisira, Conn, \& Nayar, 2014; Cochrane \& Antonczak, 2014; Cochrane, Antonczak, Guinibert, \& Mulrennan, 2014; Cochrane, Antonczak, \& Wagner, 2013; Cochrane \& Bateman, 2011; Conn et al., 2016). Given the New Zealand Productivity Commission's concern that tertiary providers are supply driven and more responsive to the government than students (New Zealand Productivity Commission, 2017, p. 5), this approach seeks to place students, the community and industry at the centre of developing curricula and delivery.

For this research, the learning and sharing of knowledge would be focused on co-design of public and environmental health curriculum delivery which is most relevant and acceptable to stakeholders, especially Māori and Pacific youth, but also to future communities and industry. Seeing our students and other stakeholders as active collaborators would empower them to think positively about their ability to make changes and master issues experienced in their social environment. The overall research question posed reflects the participatory and aspirational nature of the study with the aim of first identifying the kind of future stakeholders wish for their community and society. We have chosen 2030 as our point in time to link with the target in the Sustainable Development Goals which underpin the global public and environmental health agenda (United Nations, n.d.). 
Our overarching research question and the key sub-questions that would be asked are:

What is the vision of youth, community, industry and practitioners for a tertiary public and environmental health education which can deliver a sustainable and healthy South Auckland by 2030 ?

1. What is the vision of youth, community, industry, and practitioners for a sustainable and healthy South Auckland by 2030?

2. What skills and attributes in public and environmental health graduates are needed to make the vision a reality?

3. What tertiary teaching and learning delivery mechanisms, styles, curricula, aspects of student voice, are needed to achieve such skills and attributes?

4. How might this inform a co-design model of tertiary public and environmental health education relevant to Aotearoa New Zealand and internationally?

The next section of this paper outlines our findings from our preliminary analysis and exploration of the literature. As the project continues, this would be augmented by collaboration with key stakeholders including youth, students, and current public health professionals, members of the community, industry professionals, and government. The findings of this collaboration would result in a set of design principles that would be continuously tested and refined during the construction and implementation phase. Our stakeholders are integral to this process.

\section{Understanding the context}

\section{i. Tertiary public and environmental health education in the $21^{\text {st }}$ century}

Underlying shifts in the approach to public and environmental health now emphasise the interplay between health and broader social, cultural, economic and environmental conditions in which people are born, live and work (Baum, 2016; World Health Organization, 2010). Similarly to educational outcomes, there is clear understanding that social disparities lead to health inequities and social injustice (Marmot \& Bell, 2012). Aotearoa New Zealand has a poor record at delivering this kind of public and environmental health (Conn \& Diesfeld, 2014), tending instead within a neoliberal paradigm to focus narrowly on health education to communities, rather than wealth distribution or stewardship policies (Baum, 2016). This broader conceptualisation of the determinants of health provides the opportunity to expand the content and skills of graduates in a wide and varied inter-disciplinary manner. Alternative areas of study could include sustainable enterprise, environmental technology, digital communication, public policy and political systems.

Given the significance of the partnership with Māori under Tiriti o Waitangi, and the sizeable Māori and Pacific population in South Auckland, Māori and Pacific models of health are of utmost importance for public health practitioners. Māori models of health see whānau (extended family) as the foundation of Māori society (Ministry of Health/Manatū Hauora, 2002) and Te Whare Tapa Whā (four-sided house) is widely recognised as a theory of wellbeing among Māori. This includes te taha wairua (a spiritual dimension), te taha hinengaro (mind/intellect dimension), te taha tinana (a bodily dimension) and te taha whānau (a family dimension), along with the inclusion of Te Reo (Māori language) and mana mauri (flourishing one's integrity). Collectively these dimensions are interrelated and work in harmony to influence better health and well-being (Durie, 1985; 2001; Ministry of Health, 2015). Essentially, the core of kaupapa Māori is the catch cry 'to be Māori is the norm' where the research approach is for/with/by Māori and does not exclude or reject mainstream or other indigenous cultures (Smith, 2001; Smith 1999, 2012). 
Similarly Pacific holistic models of wellbeing incorporate the physical, emotional, spiritual and social aspects of health (Cammock, Derrett \& Sopoaga, 2014; Capstick, Norris, Sopoaga, $\&$ Tobata, 2009; Taufe'ulungaki, 2004). When all aspects are in balance, Pacific people achieve wellbeing. Mainstream health professionals tend to prioritise the individual, while Māori and Pacific concerns reflect wider cultural and environmental factors on community, land and water as a whole. This resonates with the wider emphasis on protecting the environment, a vital priority for the $21^{\text {st }}$ century.

As part of this project, in accordance with design-based research principles, the research practitioners would be informed by reframing work being undertaken in other jurisdictions on the core competencies and attributes for environmental and public health graduates. Of note is "Framing the Future" initiative undertaken in the United States by the Association of Schools \& Programs of Public Health to redefine future public health education (Association of Schools \& Programs for Public Health, 2017). Significant work has also been undertaken in Australia developing an appropriate curriculum framework for Aboriginal and Torres Strait Islanders, which may provide insight into developing curricula to reflect New Zealand's unique composition (Public Health Indigenous Leadership in Education (PHILE) Network, 2016).

\section{ii. The 21st Century tertiary environment}

Readily available knowledge, changing demographics, rapid technological advance and globalisation have led to difficulties in anticipating our future economy and therefore its workforce requirements (New Zealand Productivity Commission, 2017). Rather than seeking graduates with particular content knowledge or a specific skill set, employers are now seeking candidates with broad collaborative, strategic, problem-solving, cultural competence and inter-disciplinary skills (Spoonley, Dupuis \& De Bruin, 2004; Kivjuna, 2014; New Zealand Productivity Commission, 2017, p. 106; Careers NZ/Mana Rapuara Aotearoa, 2017). A further dimension to this is that, in our teaching experience, young people have differing expectations of the world around them - seeking more in the way of digital, online, creative, aesthetically pleasing, visual, and auditory approaches. However, as with other areas of tertiary education delivery, current public and environmental health tertiary education has traditionally focussed on known content-based curriculum, with an emphasis on written assessment.

Calls are being made for the education sector to become more resilient, innovative, sensitive to changing demands, and flexible so that it can face an uncertain future and to develop new models of education (New Zealand Productivity Commission, 2017). Internationally, there have been are similar calls for higher education to innovate in the face of a global digital society and rapidly advancing technology (Kivunja, 2014; Brennan et al., 2014). This has fuelled emerging pedagogical imperatives for shifts "to more student-centred, immersive learning experiences, deep faculty/student relationships and the development of critical thinking capacities" (Hutchings \& Quinney, 2015, p. 107; Cochrane \& Antonczak, 2014). This pedagogy can be described as "social constructivist" or, moving past this, "digital connectivist", where enabling the acquisition of learning and innovation, career and life, and digital literacy skills is paramount (Kivunja, 2014).

Aotearoa New Zealand researchers redeveloping tertiary education in the technological age argue that if the aim of education is to create productive members of a global professional society, then creating "life-long learners with a wide range of digital literacies" is essential (Cochrane \& Antonczak, 2014, p. 360). Education practitioners must move beyond simply seeing technology as a different method of delivering the same content, but rather see technology as both reframing the types of skills and attributes students will need upon graduation and enabling innovative teaching methods to create opportunities to achieve this vision. Indeed, recent research in the United States found that millennials valued a variety of learning formats (e.g., lecture based, flipped learning) and that other explanations, such as the level of engagement achieved, may be relevant for student preferences (Pettit, McCoy \& Kinney, 2017).

Pacific Health, vol 1, issue 1, 2018, ISSN 2537-8864 
Our vision is for our programmes at AUT South to equip our students with inter-disciplinary skills in critical policy development, digital and other emerging technologies, project management, sustainable business and entrepreneurship, and communications. For students to truly learn these $21^{\text {st }}$ century skills, we must as practitioners begin to move along the pedagogical continuum to "authentic student-generated collaborative learning" (Cochrane $\&$ Antonczak, 2014). While the New Zealand Productivity Commission acknowledges that innovation is occurring in many institutions, it made the overall observation that the current system does not incentivise these commitments or offer models for change (New Zealand Productivity Commission, 2017). Developing design principles for curriculum development as part of a research project would add to the growing body of knowledge in this area.

\section{iii. Improving education for all learners}

The social constructivist view discussed above also underscores the importance of seeing the educational process occurring within the context of the students' communities and lives. Recognising that traditional models of tertiary education delivery are failing to meet the needs of all learners is of particular importance in the South Auckland context, which is characterised by many groups who have historically under-performed including "first in the family to attend university, from culturally or linguistically diverse backgrounds, indigenous, of mature age and/or with a disability" (Daddow, 2016, p. 742). In Aotearoa New Zealand, the recent Productivity Commission report highlighted the learning and teaching challenges for Māori and Pacific students, those from low deprivation areas and mature students who are seeking to reskill in a time of shifting employment prospects (New Zealand Productivity Commission, 2017). Internationally, the awareness of this disadvantage has fuelled calls for culturally responsive pedagogy (Goldstein, Ick, Ratang, Hutajulu, \& Blesia, 2016), with the importance of taking this into account in curriculum design (Daddow, 2016). This also aligns with arguments for "socially responsive" curricula (Torres \& Moraes, 2006, p. 348) which maintains that education should be among other things "grounded in the lives of students", "critical" and focus on social justice (Torres \& Moraes, 2006).

In Aotearoa New Zealand, clear strategic aims exist in the Tertiary Education Strategy for enhancing the career prospects of at-risk youth and to boost the achievement of Māori and Pacific youth (Ministry of Education/Te Tāhuhu o te Mātauranga, and; Ministry of Business, Innovation and Employment/Hīkina Whakatutuki and Ministry of Education/Te Tāhuhu o te Mātauranga, 2014). There are also calls for a move from "a position previously steeped in deficit theorising of Māori learners to a position of agency that targets potential and opportunity" (MacFarlane, MacFarlane, Graham, \& Clarke, 2017, p. 277). Durie (2005) maintains that campus innovations have the potential to positively impact on Māori education experiences and this can have the flow on effect in terms of "what is good for Māori is good for the institution as a whole, enabling the fulfilment of higher goals and aspirations" (p. 12). Thus, a strengths base model that actively values all voices can draw upon the variation in contextual knowledge so that there can be collective benefit (Munford \& Sanders, 2011).

A rich vein of scholarship in Aotearoa New Zealand in relation to realising Māori potential includes concepts of "culturally responsive interactions" and "social and emotional learning" and would be utilised in this project (Smith, 2001; Hudson, Milne, Reynolds, Russell, \& Smith, 2010; MacFarlane, 2015; MacFarlane et al, 2017). In particular, MacFarlane states "intercultural relationships are foundational to ensuring that culturally safe and relevant learning environments (those that accept and celebrate diversity) and culturally responsive pedagogies are seen, heard and felt" $(2015$, p. 27$)$. In the tertiary environment, Durie has set out pathways required in the four areas of access, successful completion, high academic achievement and workforce development for the success of indigenous participation in higher education, emphasising collaboration (2005). The establishment of the Vision Mātauranga Policy is another important element passed by the current Government of ensuring Māori success and utilising the innovation potential of Māori knowledge, people and resources (Ministry of Research Science + Technology/Te Manatū Pūtaiao, 2007). 


\section{Conclusion}

We know that there is a need for a public and environmental health education which emphasises the interplay between health and broader social, cultural, economic and environmental conditions in which people are born, live and work, and addresses the social disparities which lead to health inequities and injustice Also, we know that there is a need for change to tertiary education capitalising on opportunities offered by technology, and being more responsive to students in an increasingly constructivist or heutagogical paradigm. Our ultimate aim is to develop a model for co-design that accommodates the unique cultural and ethnic makeup of the South Auckland AUT context with the opportunity for transferability across the tertiary sector, situated within a social constructivist philosophy appropriate for lifelong learning in our new digital economy and environmental challenges. It is anticipated that this may provide innovative learning and teaching experiences for students that better equip them for participation in an emerging digital society, upskill academics in best practice $21^{\text {st }}$ century learning and teaching, and may ultimately challenge traditional methods of curriculum development. We also hope that the research process would lead to increased skills and professional development of the co-design team members (students, academics, practitioners and community members), achieving transformation for all. 


\section{References}

Association of Schools and Programs of Public Health. (2017). Framing the Future. Retrieved 16 August 2017 from http://www.aspph.org/educate/framing-the-future/

Barab, S., \& Squire, K. (2004). Design-Based Research: Putting a Stake in the Ground. Journal of the Learning Sciences, 13(1), 1-14. doi:10.1207/s15327809j1s1301_1

Baum, F. (2016). The new public health (4th ed). South Melbourne: Oxford University Press.

Brennan, J., Broek, S., Durazzi, N., Kamphius, B., Ranga, M., \& Ryan, S. (2014). Study on innovation in higher education: final report. Luxembourg: European Commission Directorate for Education and Training Study on Innovation in Higher Education. Retrieved from http://eprints.1se.ac.uk/55819/1/_lse.ac.uk_storage_LIBRARY_Secondary_libfile_s hared_repository_Content_Durazzi\%2C\%20N_Study\%20innovation_Durazzi_Study\% 20innovation_2014.pdf

Cammock, R., Derrett, S., \& Sopoaga, F. (2014). An assessment of an outcome of injury questionnaire using a Pacific model of health and wellbeing. The New Zealand Medical Journal, 127(1388), 1-9. Retrieved from https://www.nzma.org.nz/journal/read-the-journal/all-issues/20102019/2014/vol-127-no.-1388/articles-cammock

Capstick, S., Norris, P., Sopoaga, F., \& Tobata, W. (2009). Relationships between health and culture in Polynesia - A review. Social Science \& Medicine, 68(7), 1341-1348. Retrieved from https://www.ncbi.nlm.nih.gov/pubmed/19195751

Careers NZ/Mana Rapuara Aotearoa (2017). Skills employers are looking for. Retrieved August 24, 2017, from https://www.careers.govt.nz/plan-your-career/not-surewhat-to-do/skills-employers-are-looking-for/

Cochrane, T., \& Antonczak, L. (2014). Implementing a Mobile Social Media Framework for

Designing Creative Pedagogies. Social Sciences, 3(3), 359-377. doi:10.3390/socsci3030359

Cochrane, T., Antonczak, L., Guinibert, M., \& Mulrennan, D. (2014). Developing a Mobile Social Media Framework for Creative Pedagogies: International Association for Development of the Information Society. Retrieved from http://ezproxy.aut.ac.nz/login?url=http://search.ebscohost.com/login.aspx?direct= true $\& \mathrm{db}=$ eric $\& \mathrm{AN}=\mathrm{ED} 557241 \%$ site $=$ eds-live

Cochrane, T., Antonczak, L., \& Wagner, D. (2013). Post-Web 2.0 Pedagogy: From StudentGenerated Content to International Co-Production Enabled by Mobile Social Media. International Journal of Mobile and Blended Learning, 5(4), 1-18. DOI: $10.4018 / \mathrm{ijmbl} .2013100101$

Cochrane, T., \& Bateman, R. (2011). Strategies for mLearning Integration: Evaluating a Case Study of Staging and Scaffolding mLearning Integration across a Three-Year Bachelor's Degree. Waikato Journal of Education, 16(1), 107-122. Retrieved from http://www.wje.org.nz/index.php/WJE/article/viewFile/74/63

Conn C, \& Diesfeld, K. (2014). Editorial: The public's health, inequalities \& social justice AUT Public Health Bulletin.

https://www.aut.ac.nz/_data/assets/pdf_file/0005/513635/Editorial-APHBConn-and-Diesfeld-finalKD16Dec.pdf

Conn, C., Said, A., Sa'uLilo, L., Fairburn-Dunlop, P., Antonczak, L., Andajani, S., \& Blake, G. O. (2016). Pacific Talanoa and Participatory Action Research: Providing a space for Auckland youth leaders to contest inequalities. The Research for Development Impact Network iii Reflecting on evidence and practice in an age of inequality. iv, 49. Australian National University. Retrieved from https://crawford.anu.edu.au/rmap/devnet/devnet/db-77.pdf

Daddow, A. (2016). Curricula and Pedagogic Potentials When Educating Diverse Students in Higher Education: Students' "Funds of Knowledge" as a Bridge to Disciplinary Learning. Teaching in Higher Education, 21(7), 741-758. https://doi.org/10.1080/13562517.2016.1183619

Durie, M. (1985). A Māori Perspective on Health. Social Science and Medicine, 20(5), 483486. Retrieved from http://www.journal.mai.ac.nz/sites/default/files/MAI_Jrnl_V3_Iss1_Cram.pdf 
Durie, M. (2001). Mauri Ora: the dynamics of Māori health. Oxford: Oxford University Press, 2001. Retrieved from https://treasury.govt.nz/sites/default/files/2007-09/tglsdurie.pdf

Durie, M. (2005). Indigenous higher education Māori experience in New Zealand. Presented at the meeting of the Australian Indigenous Higher Education Advisory Council, Canberra, Australia. Retrieved from

file:///C:/Users/em10838/Pictures/Michael\%20King\%20on\%20Maori\%20Achieve ment.pdf

Goldstein, B. L., Ick, M., Ratang, W., Hutajulu, H., \& Blesia, J. U. (2016). Using the Action Research Process to Design Entrepreneurship Education at Cenderawasih University. Procedia - Social and Behavioral Sciences, (228) 462-469. doi: 10.1016/j.sbspro.2016.07.071

Hudson M, Milne M, Reynolds P, Russell K, Smith B. (2010). Te Ara Tika: Guidelines for researchers on health research involving Māori. Auckland: Health Research Council, Aotearoa New Zealand.Retrieved from http://www.hrc.govt.nz/sites/default/files/Te\%20Ara\%20Tika\%20Guidelines\%20fo r\%20Maori\%20Research\%20Ethics.pdf

Hutchings, M., \& Quinney, A. (2015). The Flipped Classroom, Disruptive Pedagogies, Enabling Technologies and Wicked Problems: Responding to "The Bomb in the Basement". Electronic Journal of e-Learning, 13(2), 106-119. Retrieved from https://www.learntechlib.org/p/160785/

Kivunja, C. (2014). Do You Want Your Students to Be Job-Ready with 21st Century Skills? Change Pedagogies: A Pedagogical Paradigm Shift from Vygotskyian Social Constructivism to Critical Thinking, Problem Solving and Siemens' Digital Connectivism. International Journal of Higher Education, 3(3), 81-91. http://dx.doi.org/10.5430/ijhe.v3n3p81

Livingstone, A.-M., Celemencki, J., \& Calixte, M. (2014). Youth Participatory Action Research and School Improvement: The Missing Voices of Black Youth in Montreal. Canadian Journal of Education, 37(1), 283-307. Retrieved from http://journals.sagepub.com/doi/abs/10.3102/0091732X16686948

Macfarlane, A. H. (2015). Ngā tapuewae o mua mō muri: Footprints of the past to motivate today's diverse learners. Waikato journal of education/Te Hautaka Mātauranga o Waikato, 20(2), 27-38. Retrieved from http://www.wje.org.nz/index.php/WJE/article/viewFile/203/221

Macfarlane, A. H., Macfarlane, S., Graham, J., \& Clarke, T. H. (2017). Social and Emotional Learning and Indigenous Ideologies in Aotearoa New Zealand: A Biaxial Blend. In E. Frydenberg, A. J. Martin, \& R. J. Collie (Eds.), Social and Emotional Learning in Australia and the Asia-Pacific: Perspectives, Programs and Approaches (pp. 273-289). Singapore: Springer Singapore. DOI 10.1007/978-981-10-3394-0

Maibvisira, C., Conn, C., \& Nayar, S. (2014). Diverse youth voices and New Zealand public policy. Vulnerable Children and Youth Studies: An International Interdisciplinary Journal for Research, Policy and Care. doi:DOI: 10.1080/17450128.2014.963774

Marmot, M., \& Bell, R. (2012). Fair society, healthy lives. Public Health, 126(SUPPL.1), s4S10. DOI:10.1016/j.puhe.2012.05.014

McKenney, S. E., \& Reeves, T. C. (2012). Conducting educational design research. London ; New York : Routledge, 2012. Retrieved from https://dspace.ou.nl/bitstream/1820/4034/7/McKenneyReeves2012FrontMatter.pdf

Ministry of Business, Innovation and Employment/Hīkina Whakatutuki \& Ministry of Education/Te Tāhuhu o te Mātauranga. (2014). Tertiary Education Strategy, 20142019. Retrieved from https://education.govt.nz/framework/main.php/policies-andstrategies/tertiary-education-strategy/?url=/further-education/policies-andstrategies/tertiary-education-strategy/

Ministry of Education/Te Tāhuhu o te Mātauranga. Ka Hikitia, Accelerating Success 20132017: The Māori Education Strategy. Retrieved from https://education.govt.nz/ministry-of-education/overall-strategies-andpolicies/the-Māori-education-strategy-ka-hikitia-accelerating-success- 
20132017/the-Māori-education-strategy-ka-hikitia-accelerating-success-2013$2017 /$

Ministry of Health/Manatū Hauora. (2002). He Korowai Oranga - Māori Health Strategy. Wellington, New Zealand: Ministry of Health. Retrieved from https://www.health.govt.nz/system/files/documents/publications/mhs-english.pdf

Ministry of Health/Manatū Hauora. (2014). The Guide to He Korowai Oranga - Mãori Health Strategy. Wellington, New Zealand: Ministry of Health. Retrieved from http://www.health.govt.nz/publication/guide-he-korowai-oranga-Māori-healthstrategy

Ministry of Health/Manatū Hauora. (2015). Pae ora - healthy futures. Retrieved August 25, 2017, from http://www.health.govt.nz/our-work/populations/maorihealth/hekorowai-oranga/pae-ora-healthy-futures

Ministry of Health/Manatū Hauora. (2016). New Zealand Health Strategy, Roadmap of actions 2016. Wellington, New Zealand: Ministry of Health. Retrieved from http://www.health.govt.nz/system/files/documents/publications/new-zealandhealth-strategy-roadmapofactions-2016-apr16.pdf

Ministry of Research Science + Technology/Te Manatū Pūtaiao. (2007). Vision Mātauranga: Unlocking the innovation potential of Mãori knowledge, resources and people. Wellington, New Zealand: Ministry of Research Science + Technology.

Ministry of Social Development/Te Manatū Whakahiato, Minsitry of Justice/Tahū o te Ture, Ministry of Education/Te Tāhuhu o te Mātauranga, New Zealand Police, Nga Pirihimana O Aotearoa, Ministry of Youth Development/Te Manatū Whakahiato Taiohi, and Counties Manukau District Health Board. (2006). Improving outcomes for young people in Counties Manukau. Auckland Youth Support Network Plan of Action 2006. Retrieved August 28, from 2017, from https://www.msd.govt.nz/documents/about-msd-and-our-work/publicationsresources/planning-strategy/improving-outcomes-young-people/improvingoutcomes-action-plan.pdf

Munford, R., \& Sanders, J. (2011). Embracing the diversity of practice: Indigenous knowledge and mainstream social work practice. Journal of Social Work Practice, 25(1), 63-77.

New Zealand Productivity Commission. (2017). New models of tertiary education: Final Report. Wellington, New Zealand: New Zealand Productivity Commission. Retrieved from

http://www.productivity.govt.nz/sites/default/files/New\%20models\%20of\%20tertia ry\%20education\%20FINAL_3.pdf

Pettit, R., McCoy, L, Kinney, M. (2017). What millennial medical students say about flipped learning. Advances in Medical Education and Practice, 8, 487-497. http://journals.sagepub.com/doi/pdf/10.1177/2382120518765135

Public Health Indigenous Leadership in Education (PHILE) Network. (2016). National Aboriginal and Torres Strait Islander Public Health Curriculum Framework (2 $2^{\text {nd }} e d$ ). Canberra: PHILE. Retrieved from http://www.phile.net.au/files/site/docs/PHILE\%20Bulletin\%20May16.pdf

Samuelson, B. L., Smith, R., Stevenson, E., \& Ryan, C. (2013). A Case Study of Youth Participatory Evaluation in Co-Curricular Service Learning. Journal of the Scholarship of Teaching and Learning, 13(3), 63-81. Retrieved from https://files.eric.ed.gov/fulltext/EJ1017068.pdf

Smith, G. H. (2001). Mãori education: Revolution and transformative action. Canadian Journal of Native Education, 24(1), 57-67.

Smith, L. T. (Ed.). (1999). Decolonising methodologies: Research and Indigenous Peoples. Dunedin, New Zealand: University of Otago Press. Retrieved from https://nycstandswithstandingrock.files.wordpress.com/2016/10/linda-tuhiwaismith-decolonizing-methodologies-research-and-indigenous-peoples.pdf

Smith, L.T. (Ed.). (2012). Decolonizing Methodologies: Research and Indigenous Peoples (2nd ed.). Dunedin, New Zealand: Otago University Press. ISBN-13: 978-1848139503 ISBN-10: 1848139500

Spoonley, P., Dupuis, A., \& De Bruin, A. (2004). Work and working in twenty-first century New Zealand. Palmerston North, N.Z: Dunmore Press Retrieved from 
https://books.google.co.nz/books?printsec=frontcover\&vid=ISBN0864694555\&redir esc $=\mathrm{y} \# \mathrm{v}=$ onepage $\& \mathrm{q} \& \mathrm{f}=$ false

Torres, M. N., \& Moraes, S. E. (2006). Building Socially Responsive Curricula through Emancipatory Action Research: International Contexts. International Journal of Action Research, 2(3), 343-374. Retrieved from

https://www.researchgate.net/publication/320830489 The challenge of embeddin g_design_for_social_change_and_innovation_in_Higher_Education_curricula_and the _role_of_DISCERN_DesIgn_for_Social_Change_and_innovation_through_a_EuRopean Network

United Nations, (n.d.). Sustainable Development Goals. Retrieved August 28, 2017, from http://www.un.org/sustainabledevelopment/sustainable-development-goals/

Waite, L., \& Conn, C. (2011). Creating a space for young women's voices: using 'participatory video drama' in Uganda. Gender, Place \& Culture, 18(1), 115-135. https://doi.org/10.1080/0966369X.2011.535297

Wang, F. and Hannafin, M. J. (2005). Design-based Research and Technology-Enhanced Learning Environments. Educational Technology Research and Development, 53(4), 5-23. Retrieved from http://cresenciafong.com/wiki/ref:wang2005design-based

World Health Organization (2010). A Conceptual Framework for Action on the Social Determinants of Health. Geneva: WHO. Retrieved on August 28, 2017, from http://www.who.int/social_determinants/publications/9789241500852/en/ 